\title{
EFEKTIFITAS MODEL PEMBELAJARAN INQUIRY PADA MATAPELAJARAN PKN MATERI DEMOKRASI DI KELAS VIII SMPN 2 KAMAL
}

\author{
Ernawati \\ STKIP PGRI Bangkalan \\ Alyakiran5454@gmail.com
}

\begin{abstract}
Abstrak
Tujuan penelitian ini adalah untuk mengetahui aktivitas siswa, respon siswa dan ketuntasan belajar siswa, setelah mengikuti pembelajaran dengan menggunakan model pembelajaran inquiry. Jenis penelitian ini adalah pendekatan deskriptif kualitatif. Instrument yang digunakan untuk mengumpulkan data adalah lembar observasi aktivitas siswa, Angket respon siswa dan tes hasil belajar yang telah divalidasi.Dari hasil pengumpulan data, hasil analisis data dan pembahasan menunjukkan aktivitas siswa selama pembelajaran dalam kategori baik dengan ratarata 3,37 yang kedua hasil penelitian menunjukkan bahwa respon siswa terhadap pembelajaran berada dalam kategori positif dengan presentase rata-rata respon siswa yaitu 74\%. Dan hasil penelitian ini juga menggambarkan efektivitas dengan ketuntasan belajar secara klasikal dengan presentase $86 \%$ yang menunjukkan bahwa pembelajaran dapat dikatakan tuntas secara klasikal. Dari hasil penelitian dapat disimpulkan bahwa ketiga indikator aktivitas, respon, dan ketuntasan belajar siswa berada pada kategori baik, positif, dan tuntas secara klasikal.
\end{abstract}

Kata kunci: Efektivitas, Inquiri, Aktifitas Siswa, Respon Siswa, Ketuntasan Belajar

\begin{abstract}
The purpose of this study was to determine student activity, student responses and student learning completeness,after participating in learning using inquiry learning models. This type of research is a qualitative descriptive approach. The instrument used to collect data was a student activity observation sheet, a student response questionnaire and a validated learning achievement test. From the results of data collection, the results of data analysis and discussion showed student activities during learning in both categories with an average of 3.37 the second. The results showed that students"'responses to learning were in the positive category with an average percentage of student responses of $74 \%$. And the results of this study also illustrate the effectiveness with classical learning completeness with a percentage of $86 \%$ which shows that learning can be said to be completed classically. From the results of the study it can be concluded that the three indicators of student activity, response, and mastery learning are in the good, positive, and complete categories classically.
\end{abstract}

Keywords: Effectiveness, Inquiri, Student Activities, Student Responses, Mastery Learning

\section{PENDAHULUAN}

Pendidikan merupakan kebutuhan manusia yang sangat penting karena pendidikan mempunyai tugas untuk menyiapkan SDM bagi pembangunan bangsa dan negara. Kemajuan ilmu pengetahuan dan teknologi (IPTEK) mengakibatkan perubahan dan pertumbuhan kearah yang lebih kompleks. Hal ini menimbulkan masalah-masalah sosial dan tuntutan-tuntutan baru yang tidak dapat diramalkan sebelumnya, sehingga pendidikan selalu menghadapi masalah karena adanya kesenjangan antara yang diharapkan dengan hasil yang dapat dicapai dari proses pendidikan (Kristianto, 2012). Secara komprehensif, ada banyak faktor yang dapat menjadi determinan untuk mewujudkan sekolah yang efektif dan berkualitas guna menghasilkan sumber daya manusia (SDM) yang berkualitas atau bermutu. Namun bertolak dari pandangan: ' $I$ have never seen a good school without a good teacher', maka diantara banyak faktor tersebut, posisi guru tampaknya merupakan posisi paling strategis. Atas dasar itu, pengapdian terhadap persoalan guru dan profesinya merupakan hal yang sangat 
memprihatinkan bagi upaya pencapaian efektifitas sekolah ( Hosnan, 2014).

Pada umumnya, banyak siswa yang masih kurang memperhatikan mata pelajaran PKn. Ketika proses pembelajaran, siswa terlihat malas, bosan dan jenuh, sehingga tidak tercipta suasana pembelajaran yang menyenangkan. Salah satu faktor yang mempengaruhi hal tersebut adalah rendahnya minat belajar siswa dan menganggap pelajaran PKn hanya pelajaran hafalan serta banyak siswa yang kurang percaya diri ketika mengeluarkan pendapat serta menjawab pertanyaan dari guru. Wijanarko (2014) juga menemukan permasalahan lainnya, yaitu proses pembelajaran yang sering digunakan oleh guru bersifat monoton dan kurang inovatif serta belum menerapkan teknik pelaksanaan model pembelajaran.

Model adalah prosedur yang sistematis tentang pola belajar untuk mencapai tujuan belajar serta sebagai pedoman bagi pengajar dalam merencanakan dan melaksanakan aktivitas pembelajaran. Model pembelajaran adalah kerangka konseptual, yang melukiskan prosedur yang sistematis dalam mengorganisasikan pengalaman belajar untuk mencapai tujuan belajar tertentu dan berfungsi sebagai pedoman bagi para pengajar dalam merencanakan dan melaksanakan aktivitas pembelajaran. Guna mencapai hasil belajar siswa di sekolah yang maksimal dan memadai, diperlukan kreatifitas guru dalam menjalankan proses pembelajarannya. Kreativitas guru dapat menjadi entry poin dalam upaya meningkatkan pencapaian hasil belajar siswa. Kreativitas yang dimaksud adalah kemampuan guru dalam meninggalkan gagasan, ide dan hal yang dinilai mapan, rutinitas, usang dan beralih untuk menghasilkan atau memunculkan gagasan, ide atau hal baru itu terwujud ke dalam pola perilaku yang dinilai kreatif pula.

Dengan menerapkan teknik pelaksanaan model pembelajaran Inquiry diharapkan dapat memperlancar pemahaman dan memperkuat ingatan serta dapat menumbuhkan minat belajar siswa. Dengan demikian dalam memperoleh pengetahuan dan pengalaman belajar, berfikir, perasaan, dan gerak motorik kita akan secara terpadu dan seimbang dalam merespons sesuatu yang diperoleh dari belajar melalui proses menemukan. Pembelajaran inquari menekankan kepada aktivitas peserta didik secara maksimal untuk mencari dan menemukan. Artinya, pembelajaran inquari menempatkan peserta didik sebagai subjek belajar.

\section{METODE}

Metode dalam penelitian ini adalah pendekatan deskriptif kualitatif. Untuk mendapatkan data yang diharapkan, peneliti menggunakan metode observasi, angket dan tes. Subjek penelitian adalah siswa kelas VIII SMPN 2 Kamal sebanyak 29 orang siswa yang terdiri dari 12 siswa perempuan dan 17 siswa laki-laki.

Instrumen adalah alat yang digunakan untuk mengumpulkan data (Batubara\& Tarigan, 2015). Instrumen terdiri dari: 1) Lembar Aktivitas Siswa yang digunakan untuk mengumpulkan data aktivitas siswa dalam mengikuti kegiatan menggunakan model inquiry. 2) Angket Respon Siswa yang digunakan untuk mengumpulkan data tentang respon siswa terhadap pembelajaran dengan menggunakan model inquiri dan untuk mengetahui seberapa besar minat dan respon siswa terhadap pembelajaran menggunakan model inquiry. 3) Soal Tes Hasil Belajar untuk mengetahui tentang kemampuan siswa setelah diberikan perlakuan.

Teknik analisis data dilakukan sebagai berikut, analisis data aktivitas siswa untuk mengukur aktivitas siswa selama proses pembelajaran menggunakan model inquari, yaitu menggunakan rumus sebagai berikut:

$$
\text { Rata-rata pengamat }=\frac{\text { nilai } p_{1}+\text { nilai } p_{2}}{2}
$$

Ket:

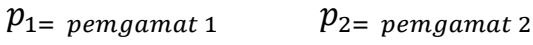

Analisis data respon siswa yang diperoleh melalui hasil angket menggunakan statistik deskriptif dengan persentase. Persentase data angket yang diperoleh dihitung berdasarkan skala Rating Scale yaitu data mentah yang diperoleh berupa angka kemudian ditafsirkan dalam pengertian kualitatif (Sugiyono, 2015). 
Berikut adalah rumus untuk memperoleh data respon siswa:

$$
\begin{gathered}
\text { Persentase Respon Siswa }= \\
\frac{\text { jumlah skor yang diperoleh siswa }}{\text { jumlah skor maksimum }} \times 100 \%
\end{gathered}
$$

Analisis data tes hasil belajar dilakukan dengan cara 1) merakapitulasi hasil penskoran terhadap jawaban siswa, 2) menentukan jumlah siswa yang tuntas, 3) menentukan ketuntasan klasikal, 4) menentukan persentase terhadap hasil penilaian yang diperoleh sebagai berikut:

$$
\begin{aligned}
& \text { Rumus ketuntasan klasikal } \\
& =\frac{\text { banyak siswa tuntas }}{\text { banyak siswa }} \times 100 \%
\end{aligned}
$$

Berdasarkan dari ketuntasan siswa, pembelajaran dikatakan efektif, jika jumlah siswa yang tuntas mencapai persentase $\geq$ $85 \%$. Efektivitas pembelajaran dengan menggunakan model pembelajaran inquiry didasarkan pada: (1) aktivitas siswa aktif, (2) respon siswa positif, (3) ketuntasan belajar secara klasikal

HASIL DAN PEMBAHASAN

\section{Aktivitas siswa}

Tabel 1. Analisis Data Aktifitas Siswa

\begin{tabular}{|c|l|c|c|c|c|}
\hline No & \multicolumn{1}{|c|}{ Aspek yang diamati } & P1 & P2 & Rata-rata & \multicolumn{1}{c|}{ Kategori } \\
\hline 1. & Mendengarkan / memperhatikan penjelasan guru & 3 & 4 & 3,5 & Sangat baik \\
\hline 2. & $\begin{array}{l}\text { Mengajukan pertanyaan / menyampaikan ide/ } \\
\text { pendapat kepada guru }\end{array}$ & 3 & 3 & 3 & Baik \\
\hline 3. & $\begin{array}{l}\text { Mencatat atau merangkum materi yang dijelaskan } \\
\text { oleh guru }\end{array}$ & 3 & 4 & 3,5 & Sangat baik \\
\hline 4. & Mengerjakan tugas / LKS & 3 & 4 & 3,5 & Sangat baik \\
\hline Jumlah & 12 & 15 & 13,5 & \\
\hline \multicolumn{2}{|l|}{ Rata-rata } & 3 & 3,75 & 3,37 & Baik \\
\hline
\end{tabular}

Sumber: hasil penelitian (2018)

Kategori:

$3,50-4,00=$ Sangat baik

$2,60-3,49=$ Baik

Aktivitas siswa selama kegiatan pembelajaran mengunakan Model Pembelajaran Inquiry pada materi demokrasi berada pada kategori baik. Observasi dilakukan oleh dua pengamat masing-masing pengamat mengamati 4 aspek yaitu mendengarkan /memperhatikan penjelasan guru, mengajukan pertanyaan/menyampaikan ide /pendapat kepada guru, mencatat atau merangkum materi yang dijelaskan guru dan mengerjakan tugas/LKS yang dilakukan terhadap 6 perwakilan siswa. Pengamat 2 mengamati 3 perwakilan siswa yang terdiri dari 2 siswa dengan kemampuan tinggi dan 1 siswa dengan kemampuan sedang yang memperoleh skor rata - rata 3,75 . Sedangkan pengamat 1 mengamati 3 perwakilan siswa yang lain yang terdiri dari 1 siswa dengan kemampuan sedang dan 2 lainnya dengan kemampuan rendah yang memperoleh skor rata-rata 3 , kemudian

$$
\begin{aligned}
& 1,70-2,59=\text { Cukup baik } \\
& 1,00-1,69=\text { Tidak baik }
\end{aligned}
$$

kedua hasil tersebut dijumlah dan dirata-rata sehingga memperoleh hasil akhir dengan rata-rata 3,37 yang berada pada kategori Baik.

Pada aspek mendengarkan / memperhatikan penjelasan guru nilai ratarata 3,5 ada dalam kategori sangat baik disini guru menjelaskan materi demokrasi dengan menggunakan Model Pembelajaran Inquary dengan jelas dan mengkondisikan kelas secara kondusif sehingga siswa mendengarkan dengan tertib. Guru memberikan umpan balik yang postif kepada siswa sehingga siswa aktif dalam mengajukan pertanyaan sehingga pada aspek kedua nilai rata-rata yang diperoleh yaitu 3 ada dalam kategori baik. Guru memberikan penjelasan yang terstruktur sesuai dengan materi ajar sehingga siswa dengan mudah mencatat materi yang sudah dijelaskan oleh guru sehingga pada aspek ini nilai rata-rata yang diperoleh yaitu 3,5 ada 
dalam kategori sangat baik. Pada aspek terakhir nilai rata-rata yang diperoleh yaitu 3,5 ada dalam kategori sangat baik, pada aspek ini siswa mengerjakan tugas dengan tertib karena soal yang diberikan guru mudah dipahami dan sesuai dengan materi yang sudah dijelaskan oleh guru.

\section{Respon Siswa}

Tabel 2. Analisis Data respon Siswa

\begin{tabular}{|c|c|c|c|c|}
\hline No & Nama Siswa & Skor respon siswa & Presentase respon siswa & Kategori \\
\hline 1. & S1 & 30 & $75 \%$ & positif \\
\hline 2. & S2 & 31 & $77,5 \%$ & positif \\
\hline 3. & S3 & 31 & $77,5 \%$ & positif \\
\hline 4. & S4 & 25 & $62,5 \%$ & Kurang positif \\
\hline 5. & S5 & 29 & $72,5 \%$ & positif \\
\hline 6. & S6 & 31 & $77,5 \%$ & positif \\
\hline 7. & S7 & 29 & $72,5 \%$ & positif \\
\hline 8. & S8 & 26 & $65 \%$ & Kurang positif \\
\hline 9. & S9 & 31 & $77,5 \%$ & Positif \\
\hline 10. & S10 & 29 & $72,5 \%$ & Positif \\
\hline 11. & S11 & 31 & $77,5 \%$ & Positif \\
\hline 12. & S12 & 30 & $75 \%$ & Positif \\
\hline 13. & S13 & 30 & $75 \%$ & Positif \\
\hline 14. & S14 & 31 & $77,5 \%$ & Positif \\
\hline 15. & S15 & 29 & $72,5 \%$ & Positif \\
\hline 16. & S16 & 31 & $77,5 \%$ & Positif \\
\hline 17. & S17 & 28 & $70 \%$ & Positif \\
\hline 18. & S18. & 32 & $80 \%$ & Positif \\
\hline 19. & S19 & 29 & $72,5 \%$ & Positif \\
\hline 20. & S20 & 31 & $77,5 \%$ & Positif \\
\hline 21. & S21 & 31 & $77,5 \%$ & Positif \\
\hline 22. & S22 & 29 & $72,5 \%$ & Positif \\
\hline 23. & S23 & 30 & $75 \%$ & Positif \\
\hline 24. & S24 & 31 & $77,5 \%$ & Positif \\
\hline 25. & S25 & 26 & $65 \%$ & Kurang positif \\
\hline 26. & S26 & 31 & $77,5 \%$ & Positif \\
\hline 27. & S27 & 29 & $72,5 \%$ & positif \\
\hline 28. & S28 & 28 & $70 \%$ & positif \\
\hline 29. & S29 & 31 & $77,5 \%$ & positif \\
\hline \multicolumn{3}{|c|}{ Jumlah } & $2,150 \%$ & \\
\hline \multicolumn{3}{|c|}{ Presentase rata-rata respon siswa $=$} & $\frac{2,150 \%}{29}=74 \%$ & Positif \\
\hline
\end{tabular}

Sumber: hasil penelitian (2018)

Kategori Respon Siswa

$$
\begin{array}{lll}
85 & \leq \text { Rs }<100 & : \text { sangat positif } \\
70<\text { Rs } \leq 85 & \text { : positif }
\end{array}
$$

Respon siswa terhadap pembelajaran mengunakan Model Pembelajaran Inquary pada materi demokrasi berada dikategori positif. Respon siswa berisi 10 pertanyaan mengenai pembelajaran yang telah dilaksanakan. Pada pertanyaan pertama pembelajaran menggunakan Model Pembelajaran Inquary menunjukkan respon positif bahwa siswa lebih paham belajar
$50<\mathrm{Rs} \leq 70 \quad$ : kurang positif

$0<\mathrm{Rs} \leq 50 \quad$ : tidak positif

materi demokrasi. Pertanyaan kedua menunjukkan respon positif bahwa materi demokrasi lebih menarik dipelajari dengan menngunakan Model Pembelajaran Inquary. Pertanyaan ketiga menunjukkan respon postif bahwa siswa senang mempelajari materi demokrasi menggunakan Model Pembelajaran Inquary. Pertanyaan keempat menunjukkan respon positif bahwa siswa 
lebih termotivasi setelah mengikuti pembelajaran menggunakan Model Pembelajaran Inquary. Pertanyaan kelima menunjukkan respon positif bahwa siswa suka dengan cara mengajar. Pertanyaan keenam menunjukkan respon positif bahwa pembelajaran menggunakan Model Pembelajaran Inquary berguna bagi siswa. Pertanyaan ketujuh menunjukkan reson positif bahwa siswa lebih aktif pada saat mengikuti pembelajaran. Pertanyaan kedelapan menunjukkan respon positif bahwa pembelajaran menggunakan Model Pembelajaran Inquary materi demokrasi mudah diingat. Pertanyaan kesembilan menunjukkan respon positif bahwa siswa tidak mengantuk saat mengikuti pembelajaran dan pertanyaan kesepuluh menunjukkan respon positif bahwa siswa tidak merasa kesulitan dalam memahami pembelajaran. Presentase dihitung persiswa kemudian dirata-rata sehingga memperoleh hasil $74 \%$. Hasil tersebut berada pada kategori positif.

\section{Tes Hasil Belajar Pada Materi Demokrasi}

Tabel 3. Analisis Data Tes Hasil Belajar

\begin{tabular}{|c|c|c|c|c|}
\hline No & Nama Siswa & KKM & Nilai & Keterangan \\
\hline 1. & $\mathrm{~S} 1$ & 70 & 30 & Tidak Tuntas \\
\hline 2. & $\mathrm{~S} 2$ & 70 & 60 & Tidak Tuntas \\
\hline 3. & S3 & 70 & 90 & Tuntas \\
\hline 4. & S4 & 70 & 70 & Tuntas \\
\hline 5. & S5 & 70 & 80 & Tuntas \\
\hline 6. & S6 & 70 & 90 & Tuntas \\
\hline 7. & S7 & 70 & 70 & Tuntas \\
\hline 8. & S8 & 70 & 90 & Tuntas \\
\hline 9. & S9 & 70 & 50 & Tidak Tuntas \\
\hline 10. & S10 & 70 & 80 & Tuntas \\
\hline 11. & S11 & 70 & 80 & Tuntas \\
\hline 12. & S12 & 70 & 70 & Tuntas \\
\hline 13. & S13 & 70 & 90 & Tuntas \\
\hline 14. & S14 & 70 & 80 & Tuntas \\
\hline 15. & S15 & 70 & 70 & Tuntas \\
\hline 16. & S16 & 70 & 80 & Tuntas \\
\hline 17. & S17 & 70 & 40 & Tidak Tuntas \\
\hline 18. & S18. & 70 & 100 & Tuntas \\
\hline 19. & S19 & 70 & 80 & Tuntas \\
\hline 20. & S20 & 70 & 70 & Tuntas \\
\hline 21. & S21 & 70 & 70 & Tuntas \\
\hline 22. & $\mathrm{~S} 22$ & 70 & 70 & Tuntas \\
\hline 23. & S23 & 70 & 80 & Tuntas \\
\hline 24. & S24 & 70 & 70 & Tuntas \\
\hline 25. & $\mathrm{~S} 25$ & 70 & 90 & Tuntas \\
\hline 26. & S26 & 70 & 80 & Tuntas \\
\hline 27. & S27 & 70 & 70 & Tuntas \\
\hline 28. & S28 & 70 & 80 & Tuntas \\
\hline 29. & S29 & 70 & 80 & Tuntas \\
\hline \multicolumn{2}{|c|}{ Total nilai rata-rata tes } & \multicolumn{3}{|c|}{$\frac{2160}{29}=74,48$} \\
\hline \multicolumn{2}{|c|}{ Jumlah siswa yang tuntas } & \multicolumn{3}{|c|}{25} \\
\hline \multicolumn{2}{|c|}{ Ketuntasan belajar siswa } & \multicolumn{3}{|c|}{$86 \%$} \\
\hline
\end{tabular}

Sumber: hasil penelitian (2018)

Ketuntasaan pembelajaran pada materi demokrasi siswa dapat dikatakan tuntas secara klasikal. Dari hasil penelitian didapatkan bahwa dari 29 siswa terdapat 25 
siswa yang telah tuntas yaitu $86 \%$ dan terdapat 4 siwa yang belum tuntas yaitu $14 \%$ maka dapat dikatakan bahwa pembelajaran menggunakan Model Pembelajaran Inquiry pada materi demokrasi di kelas VIII SMPN 2 Kamal efektif. Hal ini didasarkan pada peraturan Depdikbud yang dikutip dalam Trianto (2009) dalam jurnal (Batubara, Tarigan, 2015) bahwa suatu kelas dikatakan telah tuntas belajar jika $\geq 85 \%$ siswa di kelas telah mencapai skor $\geq \mathrm{KKM}$.

\section{DAFTAR PUSTAKA}

Ambarsari, W, Santosa, S., \& Maridi. (2013). Penerapan Pembelajaran Inkuiri Terbimbing terhadap Keterampilan Proses Sains Dasar pada Pelajaran Biologi Siswa Kelas VII SMP N 7 Surakarta . Penerapan Pembelajaran Inkuiri Terbimbing, 81-95.

Adilia, E.G. 2016. Hubungan Respon Siswa terhadap Tugas yang diterima dengan Kemampuan Memecahkan Soal Matematika Kelas IV Sekolah Dasar se-Gugus 2 Kecamatan Pengasih. Terbit di jurnal Pendidikan.

Arsyad, A. 2011. Media Pembelajaran Jakarta: Rajawali pers.

Azizah, I. 2016. Efektifitas Pembelajaran menggunakan Permainan Tradisional terhadap Motivasi dan Hasil Belajar Materi Gaya di Kelas IV MIN Ngronggot Nganjuk. Jurnal Efektivitas, 280308.

Ali, M. 2002. Guru dalam proses belajar mengajar. Bandung: Sinar Baru Algesindo.

Baharuddin, I. 2014. Efektifitas Penggunaan Media Video Tutorial Sebagai Pendukung Pembelajaran Matematika terhadap Minat dan Hasil Belajar peserta didik SMA Negeri 1 Bajo Kabupaten Luwu

\section{SIMPULAN}

Berdasarkan hasil penelitian efektifitas model pembelajaran inquiry pada mata pelajaran PKn materi demokrasi di kelas VIII SMPN 2 Kamal, dapat disimpukan bahwa penggunaan model pembelajaran inquiri dapat memberikan pembelajaran efektif, melalui pencapaian aktivitas siswa, respon siswa dan ketuntasan belajar yang berada pada kategori baik, positif dan tuntas secara klasikal.

Sulawesi Selatan. Jurnal Nalar Pendidikan, 145-151.

Dimyati, \& Moedjiono. 2009. Belajar dan Pembelajaran. Jakarta: Rineka Cipta.

Dharma, S., dkk. 2013. Tantangan guru SMK abad 21, Kementerian Pendidikan dan Kebudayaan, Direktorat Jenderal Pendidikan Menengah, Direktorat Pembinaan Pendidikan dan Tenaga Kependidikan Menengah, Jakarta.

Hamalik, O. 2011. Proses Belajar Mengajar. Jakarta: Rineka Cipta.

Hosnan. 2014. Pendekatan saintifik dan kontektual dalam pembelajaran abad 21. Bogor: Ghalia Indonesia.

Kristanto. 2012. 'Skripsi Hubungan Lingkungan Pendidikan dengan Prestasi Belajar Siswa Kelas XI Jurusan Teknik Mekanik Otomotif SMK Se-Kabupaten Sleman'. Tidak diterbitkan.

Sugiyono. 2015. Metode Penelitian Pendidikan Pendekatan Kuantitatif Kualitatif dan R\&D. Bandung: Alfabeta.

Zaini, H, dkk. 2002. Strategi Pembelajaran Aktif di Perguruan Tinggi, Yogyakarta: CTSD IAIN Sunan Kalijaga. 